

\section{Rima IX}

Besa el aura que gime blandamente las leves ondas que jugando riza; el sol besa a la nube en occidente y de púrpura y oro la matiza;

la llama en derredor del tronco ardiente por besar a otra llama se desliza; y hasta el sauce, inclinándose a su peso, al río que le besa, vuelve un beso

\section{Rima IX}

Vântul sărută-n tânguieli uşoare valurile mici ce-n joc se unduiesc; soarele-n apus sărută norul care de-atâta aur roşu nu pare pământesc; pe trunchiul încins flăcări în visare într-un sărut aprins se contopesc, iar salcia de pletengreunată sărută râul, de râu e sărutată. 